\title{
XXI. A comparison of various notations employed in "Theories of Crystal-structure," and a revision of the 230 groups of movements
}

\section{Harold Hilton}

To cite this article: Harold Hilton (1902) XXI. A comparison of various notations employed in "Theories of Crystal-structure," and a revision of the 230 groups of movements, Philosophical Magazine Series 6, 3:14, 203-212, DOI: 10.1080/14786440209462755

To link to this article: http://dx.doi.org/10.1080/14786440209462755

曲 Published online: 08 Jun 2010.

Submit your article to this journal $[\pi$

Џll Article views: 3

Q View related articles $\longleftarrow$

Citing articles: 1 View citing articles $\square$ 
Notations employed in Theories of Crystal-structure. 203 two obvious ways of explaining this peculiar rauiation. One of these is to regard the effect as due to ultra-violet light produced by heating the excited salt, this light acting on the negatively-charged salt and thereby causing a leak from its surface.

To test this view, an amalgamated zinc sphere, Z (fig.1), was attached to the lower end of the measuring system. With this arrangement, though the zinc sphere was within four millimetres of the radioactive salt, no indication of a discharge of negative electricity from the gold leaf was observed.

It seems scarcely possible that an ultra-violet radiation, capable of producing the effects observed, could be absorbed completely in passing through air at $15 \mathrm{mms}$. pressure for a distance of only four millimetres.

Probably the simpler view to take is that the salts on being heated emit a stream of negatively-charged particles or corpuscles which are drawn to the positively-charged yold leaf by the electrostatic field. and thus discharge it. If this view be correct, these negatively-charged particles must be sent out from the salt with exceedingly small velocities, otherwise we would expect the gold leaf, when initially unelectrified, to acquire at least a small negative charge.

The experiments described in this paper were conducted in the Cavendish Laboratory, and my sincere thanks are due to Professor Thomson for many valuable suggestions and much encouragement given throughout the investigation.

August 1st, 1901.

XXI. A Compurison of various Notations employed in "Theories of Crystal-structure," and a Revision of the 230 Groups of Movements. By Hanold Hilton, Magdalen College, Oxford ${ }^{*}$.

GINCE the determination of the possible groups of move$\$$ ments must hold an important position in any future theories of crystal structure; and since the mathematical theory of these groups has been practically brought to a completion; it seemed advisable to draw up tables comparing the different notations of the various workers on the subject, with the hope that at the same time a judgment might be formed on the correctness of the staiement that the number of groups of movements which are applicable to crystallography is 230 .

* Communicated by the Author. 
204 Mr. H. Hilton: A Comparison of Various

Mr. W. Barlow and Mr. G. F. H. Smith have began a similar piece of work together for the latter reason. When they heard that $I$ had independently finished such a comparison, they placed my work side by side with their own to some extent, and found that we agreed. They also kindly gave me some useful bints. I take this opportunity of thanking them, and also Prof. H. A. Miers, who has very kindly given me his help throughout.

The chief workers on the subject have been C. Jordan (Annali di Matematica pura ed applicata, Serie 2, Band ii. 1869); L. Sohncke (Entwickelung einer Theorie der Krystallstruktur, Leipzig, 1879); E. von Fedorow (Zeitschr. f. Kryst. u. Min. xxiv. 1895); A. Schoenflies (Mathematische Annalen, xxviii., xxix. (1887), \& xxxiv. (1889), and Krystallsysteme und Krystallstructur, Leipzig, 1891); and W. Barlow (Zeitschr. f. Kryst. u. Min. xxiii. 1895). (Fedorow's work was published in Russian in 1890.)

The notations are taken from the periodicals or books just named, and compared in the tables given below.

I have myself carefully compared Barlow's notation with that in Schoenflies' book; and have also compared the two notations used by Schoenflies in his book and in the Mathematische Annalen. Fedorow has compared his own work with that of Barlow* and of Schoenflies $\uparrow$, and thus indirectly has compared Schoenflies' and Barlow's work. If there was any discrepancy between this and my own direct comparison, I have investigated the case carefully, and have given a note on the subject. The comparison of Schoenflies' work (and hence of Fedorow's and Barlow's) with that of Jordan and Sohncke is that given by Schoenflies in the Mathematische Annalen.

The diagrams given by Fedorow $\ddagger$ are not always correct; thus e. g. the diagrains of $\hat{\mathrm{o}} \overline{\mathrm{z}} s, 63 s, 64 s, 49 h, 50 h, 91 a, 92 a$, should be identical with those of $18 s, 20 s, 21 s, 19 h, 24 h$, $29 a, 21 a$, respectively, which is not always the case; in. particular, as Mr. Smith has kindly pointed out to me, the diagrams of $64 s$ and $50 \mathrm{~h}$ are identical and both wrong. It would be beyond the scope of this paper to prepare fresh diagrams. I hope to do this on some future occasion.

It is as well to call attention to the fact that Fedorow altered his notation a little in Zeitschr. Kryst. Min. xxiv. pp. $233 \& 237$; that Barlow pointed out a few errors in his previous work in Zeitschr. Kryst. Min. xxv. pp. 86 \& 87;

* Zeitschr. Kryst. Min. xxiv. pp. 242-244.

+ Ibid. xx. pp. 48-61.

$\ddagger$ Tafeln V., VI., Zeitscinr. Kryst. Min. xxiv. 
Notations employed in Theories of Crystal-structure. 205 and that Schoenflies did the sane in Kystallsysteme und Krystallstructur, p. 622.

In some cases Schoenflies (in his paper in the Math. Annalen, xxxiv.) gave the same symbol to two groups. Where one of these groups is derived from the other by the substitution of the operation $S(\tau)$ for $S$, or $S(t+\tau)$ for $S(t)$, I have underlined the symbol in the case of the latter group. Similarly he gives the symbol $\mathrm{V}_{3}$ as representing 3 distinct groups.

For convenience of printing, English capitals are substituted for German in the symbols of Schoenfies, as no error can thereby arise.

An asterisk against a symbol means that a reference is made to it in the notes following the tables.

\section{TABLE I.}

\begin{tabular}{|c|c|c|c|c|c|}
\hline $\begin{array}{c}\text { A. Schoenfies. } \\
\text { Krystallsyst. } \\
\text { u. Krystall- } \\
\text { structur, } \\
1891 .\end{array}$ & $\begin{array}{c}\text { A. Schoenfies. } \\
\text { Mathem. An- } \\
\text { nalen, xyviii. } \\
\text { p. } 319 ; \text { xxix. } \\
\text { p. } 50 \text { (1887); } \\
\& \text { xxiv. } \\
\text { (1889). } 172\end{array}$ & $\begin{array}{l}\text { C. Jordan. } \\
\text { Annali di } \\
\text { Matema- } \\
\text { tica pura } \\
\text { ed appl. } \\
\text { Band ii. } \\
\text { 1869. }\end{array}$ & $\begin{array}{c}\text { L. Sohncke. } \\
\text { Entwickel- } \\
\text { ung einer } \\
\text { Theorie der } \\
\text { Krystall- } \\
\text { struktur, } \\
\text { 1879. }\end{array}$ & $\begin{array}{c}\text { W. Barlow. } \\
\text { Zeitschr. f. } \\
\text { Krystall. u. } \\
\text { Min. xxiii. } \\
\text { pp. 1-63 } \\
\text { (1894). }\end{array}$ & $\begin{array}{l}\text { E. v. Fedorow. } \\
\text { Zeitschr. } \\
\text { f. Kryst. u. } \\
\text { Min. xxiv. } \\
\text { pp. } 232-237 \\
\text { (1895). }\end{array}$ \\
\hline$C_{1}$ & no symbol & 3 & 1 & 65 & $1 \mathrm{~s}$ \\
\hline $\mathrm{C}_{2}{ }^{2}$ & $\mathrm{C}_{1}(2)$ & 29 & 2 & 63 & $3 s$ \\
\hline $\mathrm{C}_{2}^{2}$ & $\mathbf{C}_{2}(2)$ & 31 & 3 & 62 & $1 a$ \\
\hline $\mathrm{C}_{2}{ }^{3}$ & $\mathrm{O}_{3}(2)$ & 33 & 4 & 64 & 48 \\
\hline $\mathrm{V}^{\mathrm{i}}$ & $v_{4}$ & 91 & 5 & 56 & $9 \mathrm{~s}$ \\
\hline$\nabla^{2}$ & $\mathbf{v}_{\gamma}$ & abs. & 6 & 53 & $4 a$ \\
\hline$v^{3}$ & $v_{s}$ & 93 & 12 & 55 & $7 a$ \\
\hline$V^{i}$ & $\nabla_{s}$ & abs. & 14 & 54 & $8 a$ \\
\hline $\mathrm{V}^{5}$ & $\mathbf{V}_{\mathrm{g}}$ & abs. & * 9,13 & 57 & $5 a$ \\
\hline $\mathbf{V}^{6}$ & $v_{3}$ & 92 & 7 & 59 & $10 s$ \\
\hline$v^{7}$ & $\nabla_{2}$ & 99 & 8 & 61 & 128 \\
\hline $\mathrm{V}^{8}$ & $\nabla_{1}$ & 100 & 10 & 60 & $11 \mathrm{~s}$ \\
\hline$\nabla^{9}$ & $\mathbf{v}_{5}^{2}$ & 101 & 11 & 58 & $6 a$ \\
\hline $\mathrm{C}_{3}{ }^{1}$ & $\mathrm{C}_{1}(\mathbf{3})$ & 61 & 17 & 48 & $38 s$ \\
\hline $\mathrm{C}_{3}{ }^{2}$ & $\mathrm{C}_{2}(3)$ & 63 & 15 & 42 & $68 a$ \\
\hline $\mathrm{C}_{3}{ }^{3}$ & $\mathrm{C}_{2}^{\prime}\left({ }^{\prime}\right)$ & 64 & 16 & 43 & $69 a$ \\
\hline $\mathrm{C}_{3}{ }^{4}$ & $\mathrm{O}_{3}(3)$ & 62 & 18 & 51 & $39_{8}$ \\
\hline $\mathrm{D}_{3}^{1}$ & $D_{1}(3)$ & 130 & 21 & 49 & $* 45 s$ \\
\hline $\mathbf{D}_{3}{ }^{2}$ & $D_{3}(3)$ & abs. & 25 & 50 & * 448 \\
\hline $\mathbf{D}_{3}^{8}$ & $\mathbf{D}_{2}(3)$ & 132 & 19 & 44 & * $72 a$ \\
\hline $\mathrm{D}_{3}{ }^{4}$ & $D_{4}(3)$ & abs. & 23 & 46 & * $70 a$ \\
\hline${D_{3}}^{5}$ & $\mathbf{D}_{2}^{\prime}{ }^{\prime}(3)$ & 133 & 20 & 45 & * $73 a$ \\
\hline $\mathrm{D}_{3}{ }^{6}$ & $\mathbf{D}_{4}^{\prime}(\mathbf{3})$ & abs. & 24 & 47 & * $71 a$ \\
\hline $\mathrm{D}_{3}{ }^{7}$ & $\mathbf{D}_{5}(\mathbf{3})$ & 131 & 22 & 52 & 468 \\
\hline
\end{tabular}


206 Mr. H. Hilton: A Comparison of Various

Table I. (continued).

\begin{tabular}{|c|c|c|c|c|c|}
\hline $\begin{array}{l}\text { A. Schoenflies. } \\
\text { Krystallsyst. } \\
\text { u. Krystall- } \\
\text { structur, } \\
1891 .\end{array}$ & $\begin{array}{c}\text { A. Sclinenfiles. } \\
\text { Mathem. An- } \\
\text { naien. rxviii. } \\
\text { p. } 319 \text {; xxix. } \\
\text { p. } 50 \text { (1887); } \\
\text { \&xxiv. p. } 172 \\
\text { (1889). }\end{array}$ & $\begin{array}{l}\text { C. Jordan. } \\
\text { Annali di } \\
\text { Matema- } \\
\text { tica pura } \\
\text { ed appl. } \\
\text { Band ii. } \\
\mathbf{1 8 6 9 .}\end{array}$ & $\begin{array}{c}\text { L. Sohncke, } \\
\text { Entwickel- } \\
\text { ung einer } \\
\text { Theorie der } \\
\text { Krystall- } \\
\text { struktur, } \\
\text { 1879. }\end{array}$ & $\begin{array}{l}\text { W. Barlow. } \\
\text { Zeitschr. f. } \\
\text { Krystall. u. } \\
\text { Min. Iriii. } \\
\text { pp. 1-63 } \\
\text { (1894). }\end{array}$ & $\begin{array}{l}\text { E. v. Fedoroto. } \\
\text { Zeitschr. } \\
\text { f. Kryst. u. } \\
\text { Min. xriv. } \\
\text { pp. } 232-237 \\
(1895) .\end{array}$ \\
\hline $\mathrm{C}_{4}{ }^{1}$ & $C_{1}(4)$ & 54 & 30 & 34 & $22 \mathrm{~s}$ \\
\hline $\mathrm{O}_{4}^{2}$ & $\mathrm{C}_{2}(4)$ & 55 & 26 & 26 & $30 a$ \\
\hline $\mathrm{C}_{4}{ }^{3}$ & $\mathrm{C}_{3}(4)$ & 56 & 29 & 29 & $33 a$ \\
\hline $\mathrm{C}_{4}{ }^{4}$ & $\mathbf{O}_{2}^{\prime}(4)$ & 57 & 27 & 27 & $31 a$ \\
\hline $\mathrm{C}_{4}{ }^{5}$ & $O_{5}(4)$ & 58 & 31 & 38 & 238 \\
\hline $\mathbf{C}_{t}{ }^{6}$ & $\mathrm{O}_{4}(4)$ & 59 & 28 & 38 & $32 a$ \\
\hline$D_{4}^{1}$ & $\mathrm{D}_{1}(4)$ & 116 & 36 & 39 & $30 \mathrm{~s}$ \\
\hline $\mathrm{D}_{4}^{2}$ & $\mathrm{D}_{2}(4)$ & 124 & 41 & 40 & $43 a$ \\
\hline $\mathrm{D}_{4}^{3}$ & $\mathrm{D}_{3}(4)$ & 117 & 32 & 30 & * $44 a$ \\
\hline $\mathrm{D}_{4}{ }^{4}$ & $D_{4}(4)$ & 125 & 38 & 32 & * $48 a$ \\
\hline $\mathrm{D}_{4}^{3}$ & $D_{5}(4)$ & 118 & 35 & 36 & $47 a$ \\
\hline $\mathrm{D}_{4}{ }^{6}$ & $\mathbf{D}_{\mathrm{a}}(4)$ & 126 & 40 & 37 & $50 a$ \\
\hline $\mathrm{D}_{4}{ }^{7}$ & $\mathrm{D}_{3}{ }^{\circ}(4)$ & 119 & 33 & 31 & * $45 a$ \\
\hline $\mathrm{D}_{4}{ }^{8}$ & $D_{4}^{\prime}(4)$ & 127 & 39 & 33 & * $49 a$ \\
\hline $\mathrm{D}_{4}{ }^{9}$ & $D_{7}(4)$ & 120 & 37 & 41 & $31 s$ \\
\hline $\mathrm{D}_{4}{ }^{10}$ & $D_{8}(4)$ & 121 & 34 & 35 & $46 a$ \\
\hline $\mathbf{C}_{6}{ }^{1}$ & $C_{1}(6)$ & 47 & 47 & 23 & $49 \mathrm{~s}$ \\
\hline $\mathrm{C}_{6}{ }^{2}$ & $\mathrm{C}_{2}(6)$ & 48 & 42 & 14 & $74 a$ \\
\hline $\mathrm{C}_{6}{ }^{3}$ & $O_{2}^{\prime}(5)$ & 52 & 43 & 15 & $75 a$ \\
\hline $\mathrm{C}_{8}{ }^{4}$ & $\mathrm{C}_{3}(6)$ & 49 & 44 & 16 & $76 a$ \\
\hline $\mathrm{O}_{8}{ }^{5}$ & $\mathrm{C}_{3}^{\prime}(6)$ & 51 & 45 & 17 & $77 a$ \\
\hline $\mathbf{O}_{6}{ }^{B}$ & $\mathrm{O}_{4}(6)$ & 50 & 46 & 20 & $78 a$ \\
\hline $\mathrm{D}_{6}{ }^{1}$ & $\mathrm{D}_{1}(6)$ & 108 & 53 & 25 & 548 \\
\hline $\mathrm{D}_{6}^{2}$ & $\mathrm{D}_{2}(6)$ & 109 & 48 & 18 & $82 a$ \\
\hline $\mathrm{D}_{6}{ }^{3}$ & $\mathrm{D}_{2}^{\prime}(6)$ & 113 & 49 & 19 & $83 a$ \\
\hline $\mathrm{D}_{0}{ }^{4}$ & $\mathrm{D}_{3}(6)$ & 110 & 50 & 21 & $84 a$ \\
\hline $\mathrm{D}_{6}^{\bar{j}}$ & $\mathrm{D}_{3}^{\prime}(6)$ & 112 & 51 & 22 & $85 a$ \\
\hline $\mathrm{D}_{6}{ }^{6}$ & $D_{4}(6)$ & 111 & 52 & 24 & $86 a$ \\
\hline$T^{0}$ & $\mathbf{T}_{3}$ & 150 & 54 & 7 & $59 s$ \\
\hline $\mathbf{T}^{2}$ & $\mathrm{~T}_{2}$ & 164 & 55 & 6 & $61 s$ \\
\hline $\mathbf{T}^{3}$ & $\mathrm{~T}_{\mathrm{\tau}}$ & 151 & 56 & 10 & $60 s$ \\
\hline $\mathbf{T}^{\mathbf{t}}$ & $T_{\overline{0}}$ & 155 & 58 & 1 & $89 a$ \\
\hline $\mathrm{T}^{5}$ & $\mathrm{~T}_{4}$ & 156 & 57 & 2 & $90 a$ \\
\hline $\mathrm{O}^{1}$ & $\mathrm{O}_{4}$ & 166 & 59 & 12 & $68 s$ \\
\hline $\mathrm{O}^{2}$ & $\mathrm{O}_{3}$ & 169 & 64 & 11 & $98 a$ \\
\hline $\mathrm{O}^{3}$ & $\mathrm{O}_{2}$ & 168 & 60 & 8 & $70 s$ \\
\hline $\mathrm{O}^{4}$ & $\mathrm{O}_{3}$ & 172 & 63 & 9 & $97 a$ \\
\hline $\mathrm{O}^{\overline{5}}$ & $\mathrm{O}_{1}$ & 167 & 61 & 13 & 698 \\
\hline $0^{\circ}$ & $\mathrm{O}_{\mathrm{T}}$ & 170 & 65 & 3 & $94 a$ \\
\hline $\mathrm{O}^{\pi}$ & $\mathrm{O}_{7}^{\prime}$ & 171 & 66 & 4 & $95 a$ \\
\hline $\mathrm{O}^{\mu}$ & $\mathrm{O}_{\mathrm{B}}$ & abs. & 62 & 5 & $96 a$ \\
\hline
\end{tabular}


Notations employed in Theories of Crystal-structure. 207

The work of drawing up the tables has led me to the conclusion that the number of possible groups of movements which contain 3 independent translations which are not infinitesimal, is really 230 .

Notes.-Sohncke's groups 9 and 13 are identical, as Schoenflies pointed out.

Fedorow gives * $44 s=\mathrm{D}_{3}^{1}, 45 s=\mathrm{D}_{3}^{2}, 70 a=\mathrm{D}_{3}^{3}, 71 a=\mathrm{D}_{3}^{5}$, $72 a=\mathrm{D}_{3}^{4}, 73 a=\mathrm{D}_{3}^{6}$, in his table of his own and Schoenflies' results. That this is wrong appears from his own words on p. 228 of the Zeitschr. f. Kryst. u. Min. xxiv. Similarly he has wrongly compared $55 s=\mathrm{D}_{3 d}^{\prime}, 56 s=\mathrm{D}_{3 d}^{3}, 45 h=\mathrm{D}_{3 d}^{2} 46 h=$ $\mathrm{D}_{3 d}^{4}, 47 s=\mathrm{D}_{3 h}^{1}, 48 s=\mathrm{D}_{3 h}^{3}, 42 h=\mathrm{D}_{3 h}^{2}, 43 h=\mathrm{D}_{3 h}^{4}$.

Again, he gives in the same place $44 a=\mathrm{D}_{4}^{4}, 45 a=\mathrm{D}_{4}^{8}$, $48 a=\mathrm{D}_{4}^{3}, 49 a=\mathrm{D}_{4}^{7}$; which is incorrect as appears from p. 229 of the Zeitschr. $f$. Kryst. u. Min. xxiv., and from Table V. at the end of the same volume.

In Barlow's tablet there is a small error; there he says that $58 \mathrm{~B}_{1}, 58 \mathrm{~B}_{2}, 58 \mathrm{~B}_{3}$ are of type 62 ( 3 of Sohncke), so specialized that its axes lie as those of the type 58 or 60 , (11 or 10 of Sohncke); now these two last groups, which are. $\mathrm{V}^{9}$ and $\mathrm{V}^{8}$ of Schoenflies, belong to Schoenflies' Raumgitier $\Gamma_{v}{ }^{\prime \prime \prime}$ and therefore all their 3 series of binary axes are of type $\mathrm{C}_{2}^{3}$, not $\mathrm{C}_{2}^{2}$ (3 of Sohncke). For "62 (3 of Sohncke)" should be read " 64 (4 of Sohncke)."

$\mathrm{V}_{h}^{27}$ appears as " $\mathrm{V}_{k}^{24}$ " on $\mathrm{p}^{2} 51$ of the Zeitschr. f. Kryst. u. Min. xx.-obviously a misprint. The corresponding group $\left(58 a_{2}\right)$ of Barlow is not given quite correctly by him. Hegives as the position of the centre "On a line midway between two neighbouring screw-axes of different sorts in its point of intersection with a rotation-axis." This would make his types $58 a_{1}$ and $58 a_{2}$ identical, and the same as Schoenflies" $\mathrm{V}_{b}^{28}$; the last phrase should run " midway between its points of intersection with a rotation axis."

* Zeitschr. Kryst. Min. xx. (1892) p. 66.

+ Ibid. xxiii. (1895) p. 56. 
208 Mr. H. Hilton: A Comparison of Various

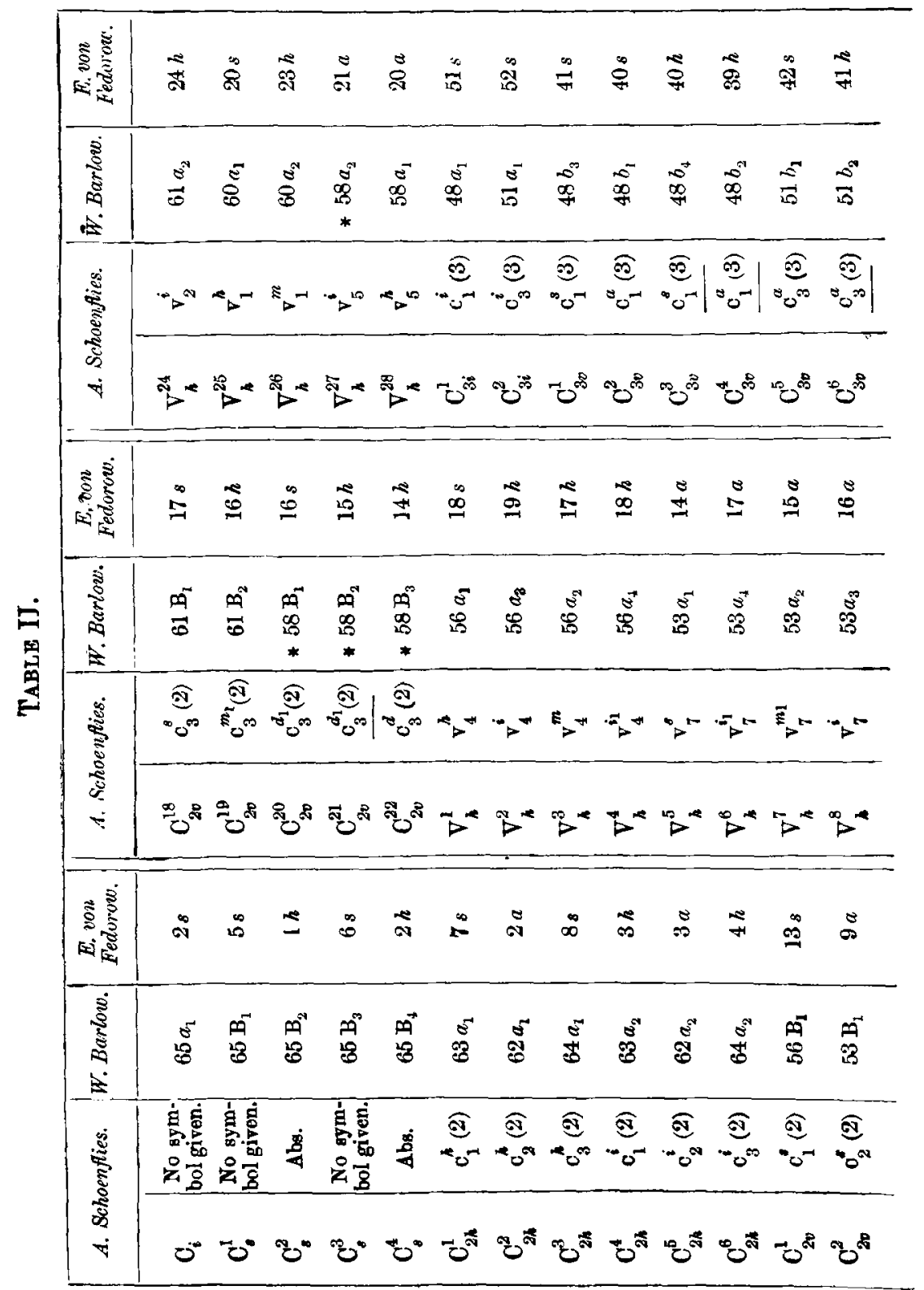


Notations employed in Theories of Crystal-structure. 209

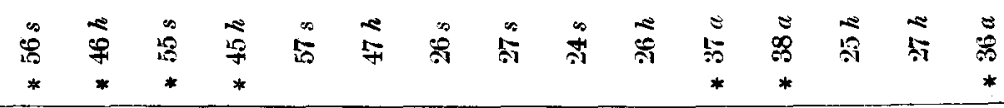

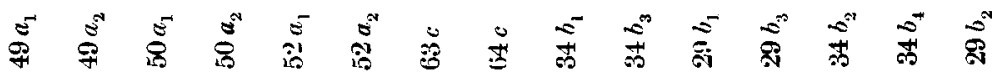

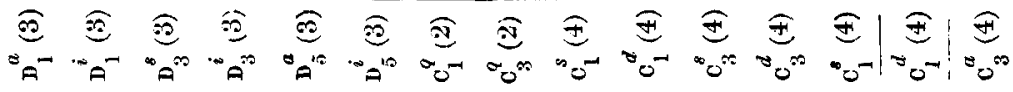

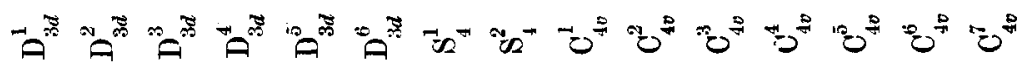

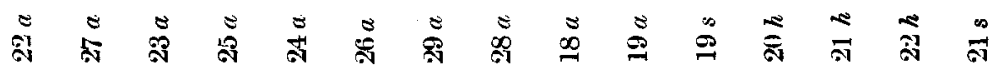

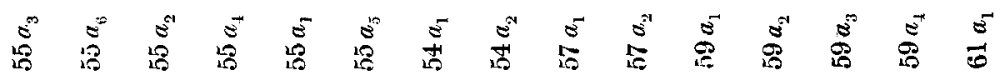

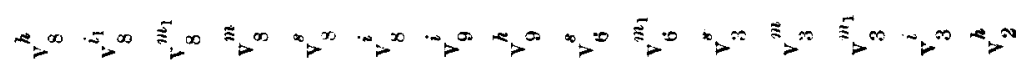

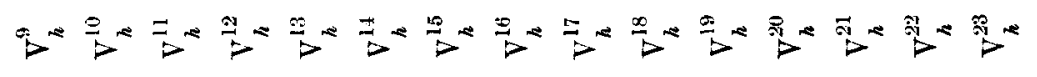

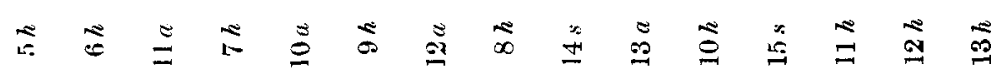

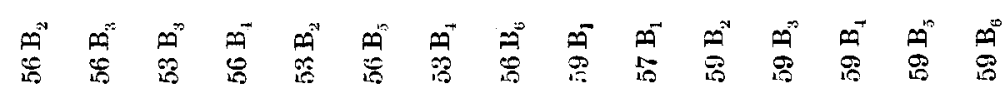

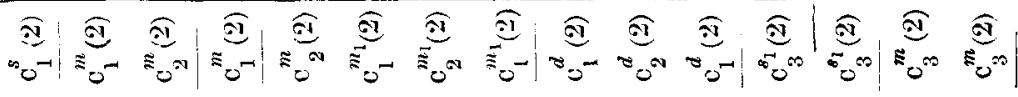

ชิ ชิ

Plil. Mag. S. b. Vol. 3. No. 14. Fet. 1902. 
210 Mr. H. Hilton : A Comparison of Various

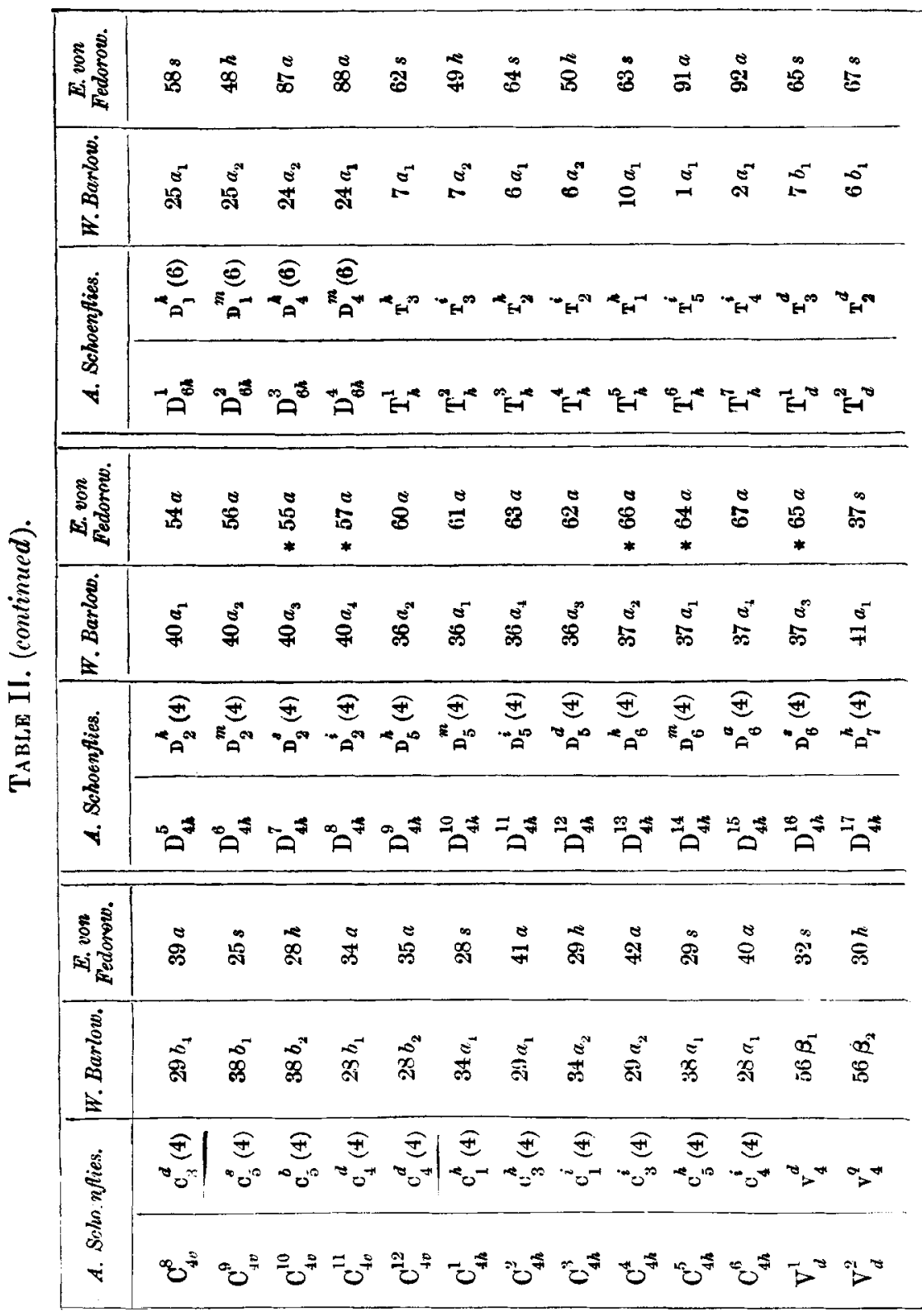


Notations employed in Theories of Crystal-structure. 211

ஆ

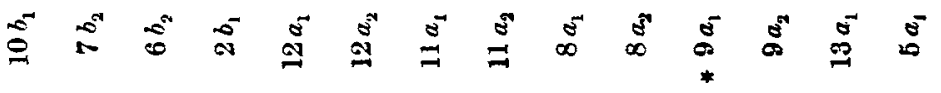

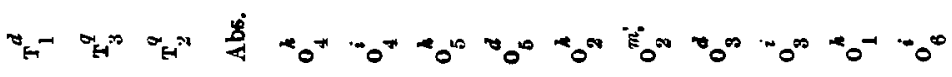

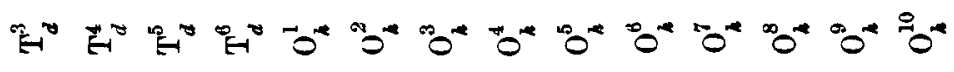

ஓ

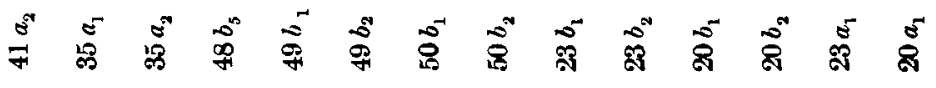

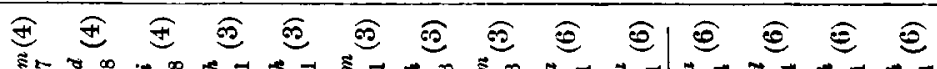

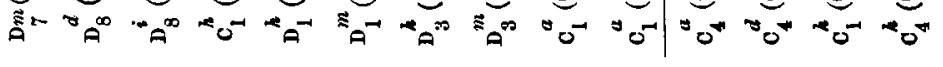

ด ค ค ค ค

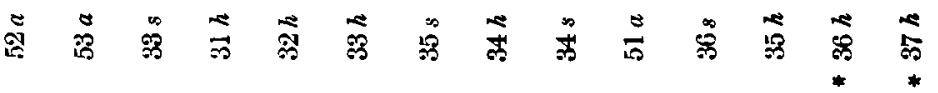

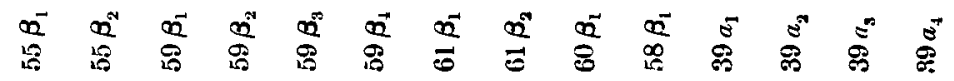

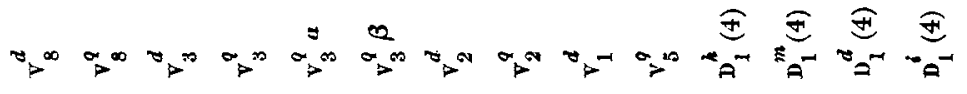

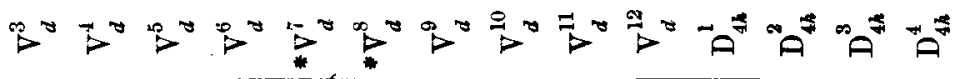




\section{Mr. P. J. Kirkby on the Electrical Conductivities}

Schoenflies does not appear to give his groups $V_{d}^{7}$ and $V_{d}^{8}$ quite correctly*; he puts the plane of the operations $S_{d}\left(\tau_{d}\right)$, $\mathbf{S}_{d}\left(\tau_{d}+\tau_{z}\right)$ in the same position as the operations $S_{d}$ and $\mathrm{S}_{d}\left(\tau_{\varepsilon}\right)$ of $\mathrm{V}_{d}^{5}$ and $\mathrm{V}_{d}^{6}$; but in that case the operations referred to would not bring the axes of $V^{6}$ into self-coincidence, as is necessary. Barlow gives the position of the plane quite correctly on p. 54, Zeitschr. Kryst. u. Min. xxiii.; and this remark agrees with Schoenflies' own treatment of these groups in the Math. Annalen, xxxiv.

Fedorow's comparison of his groups $36 h, 37 h, 55 a, 57 a$, $60 a, 61 a, 65 a, 66 a$ with Barlows types seems to be incorrect, judging by the Tables V. and VI. given at the end of the 24th volume of the Zeitschr.f. Kryst. u. Min.; as is also his comparison of $36 a, 37 a, 38 a, 64 a, 65 a, 66^{6} a$ with the corresponding groups of Schoenflies.

Fedorow compares $72 s, 73 s$ with $\mathrm{O}^{9}$ and $\mathrm{O}^{5}$; an obvious misprint for $\mathrm{O}_{h}^{9}$ and $\mathrm{O}_{h}^{5}$.

Fedorow's remark on Barlow's type $9 a_{1}$ (Zeitschr. Kryst. u. Min. xxiv. p. 244j seems not to be accurate. The position of the inversion centre given by Barlow agrees entirely with that given by Schoentlies, and involves symmetry planes parallel, not to the surface planes, but to the diagonal planes of the cube.

XXII. On the Electrical Conductivities produced in Air by the Motion of Negative Ions. By P. J. KrRквY, M.A., Fellow of New College, Oxford + .

IN the February number of the Philosophical Magazine for 1901 Prof. Townsend described in detail a series of experiments by which he demonstrated the remarkable fact that negative ions produced in a gas are capable of disintegrating other molecules with which they collide, and thus generate other ions by collision. As this adds one more to the few known methods by which ions are produced, the discovery opens up a new field of research. A series of experiments were given (J.S. Townsend and P. J. Kirkby) in the June number of the Phil. Mag. 1901, which proved that the same results which apply to air apply also to hydrogen and carbonic acid gas. These researches exhibited the extraordinary difference in the behaviour of positive and negative ions. It seemed therefore desirable further to emphasize this difference,

* Krystallsysteme und Krystallstructur, p. 497.

+ Communicated by Prof. J.S. Townsend. 